\title{
Rhodotorula subericola sp. nov., an anamorphic basidiomycetous yeast species isolated from bark of Quercus suber (cork oak)
}

Correspondence
C. Belloch
belloch@iata.csic.es

\author{
C. Belloch, ${ }^{1}$ M. Villa-Carvajal, ${ }^{2}$ M. L. Álvarez-Rodríguez ${ }^{3}$ and J. J. R. Coque ${ }^{3}$ \\ 1Departamento de Biotecnología, Instituto de Agroquímica y Tecnología de los Alimentos, \\ CSIC, 46100 Burjassot, Valencia, Spain \\ ${ }^{2}$ Centro Tecnológico AINIA, Parque Tecnológico de Valencia, 46980 Paterna, Valencia, Spain \\ ${ }^{3}$ Instituto de Biotecnología de León (INBIOTEC), Parque Científico de León, 24006 León, \\ Spain
}

\begin{abstract}
Two yeasts strains, $\mathrm{Y}-31^{\top}$ and $\mathrm{Y}-20 \mathrm{~B}$, pertaining to a previously unknown yeast species were isolated from bark of cork oak in Spain. Physiological characterization revealed a pattern of assimilation of carbon and nitrogen compounds compatible with members of the genus Rhodotorula. From sequence analysis of the D1/D2 region of the 26S rRNA gene, Rhodotorula cycloclastica and Rhodotorula philyla were related to the unknown species. Phylogenetic reconstruction based on the D1/D2 region of the 26S rRNA gene showed that the novel species clustered in a branch together with $R$. cycloclastica. The name Rhodotorula subericola sp. nov. is proposed, with isolate $\mathrm{Y}-31^{\top}$ (=CECT $11976^{\top}=$ CBS $\left.10442^{\top}\right)$ the type strain of this novel taxon in the Microbotryum lineage, subclass Microbotryomycetidae, class Urediniomycetes of basidiomycetous yeasts.
\end{abstract}

During a survey of microbial biota in the manufacturing process of cork stoppers in Spain, several bacteria, yeasts and filamentous fungi were isolated and identified (ÁlvarezRodríguez et al., 2002, 2003; Villa-Carvajal et al., 2004). Physiological characterization and RFLPs of the ITS-5.8S rDNA region indicated that yeast isolates $\mathrm{Y}-31^{\mathrm{T}}$ and $\mathrm{Y}-20 \mathrm{~B}$ represented unique yeasts. Analysis of the $26 \mathrm{~S}$ rRNA D1/D2 domain sequences of strains $\mathrm{Y}-31^{\mathrm{T}}$ and $\mathrm{Y}-20 \mathrm{~B}$ showed them to be identical and that they could not be ascribed to a recognized species. BLAST analysis yielded the highest similarity value, $95 \%$, with three strains of Rhodotorula sp. CBS $8445^{\mathrm{T}}$, CBS $8446^{\mathrm{T}}$, CBS 8447 and CBS $8448^{\mathrm{T}}$, and the species Rhodotorula philyla, therefore Villa-Carvajal et al. (2004) concluded that isolates $\mathrm{Y}-31^{\mathrm{T}}$ and Y-20B represented a novel species in the genus Rhodotorula although formal description was not given. Scorzetti et al. (2002) placed these Rhodotorula species in a tight cluster in the Microbotryum lineage and, recently, Thanh et al. (2004) described Rhodotorula cycloclastica, Rhodotorula retinophila and Rhodotorula terpenoidalis to accommodate CBS 8447 and CBS $8448^{\mathrm{T}}$, CBS $8446^{\mathrm{T}}$ and CBS $8445^{\mathrm{T}}$, respectively.

In this study, phenotypic characterization of strains $\mathrm{Y}-31^{\mathrm{T}}$ and Y-20B and phylogenetic analysis based on the sequences of the D1/D2 region of the 26S rRNA gene and ITS-5.8S

The GenBank/EMBL/DDBJ accession numbers for the 26S rRNA and ITS-5.8S rRNA gene sequences of strain CECT $11976^{\top}$ are AY296052 and DQ870625, respectively.
rDNA region were performed. The name Rhodotorula subericola sp. nov. is proposed to accommodate these two strains.

\section{Collection site and isolation of the strains}

Cork was sampled in the province of Badajoz (Extremadura, Spain). Badajoz is in the west of Spain and occupies a surface area of $1500 \mathrm{~km}^{2}$. The weather is continental with influence from the Atlantic Ocean, characterized by mild winters with minimum mean temperatures of $3.2^{\circ} \mathrm{C}$ and maximum mean temperatures of $13.9^{\circ} \mathrm{C}$. Summers are warm with minimum mean temperatures of $17.0^{\circ} \mathrm{C}$ and maximum mean temperatures of $34.3^{\circ} \mathrm{C}$. Badajoz has a rainy season from October to April with precipitation between 50 and $80 \mathrm{~mm}$, while the rest of the year it is below $30 \mathrm{~mm}$. Cork is produced by Quercus suber L. (Fam. Cupuliferae) and consists of the exterior layers of the bark beneath the epidermis, which develop extraordinarily in these species, becoming thick and of the peculiar spongy consistency which characterizes cork. Cork is extracted every 11 years from the trees. Then, cork planks are stored in the fields for some time, even years, before they are used to make cork stoppers.

Yeast strains $\mathrm{Y}-31^{\mathrm{T}}$ and $\mathrm{Y}-20 \mathrm{~B}$ were isolated in Spain from bark of cork oak at the initial stages of the manufacturing process of cork stoppers (Álvarez-Rodríguez et al., 2003). 


\section{Phenotypic characterization of yeast isolates}

Morphology of the yeasts was studied using a light microscope (Nikon Eclipse E800). Physiological and morphological characterization of the strains was performed according to standard methods (Yarrow, 1998).

\section{Sequencing and phylogenetic analysis}

Yeast cells picked from 48-h-old colonies were directly used in PCR reactions. The D1 and D2 domains of the 26S rRNA gene were amplified using the external primers NL-1 and NL-4 (O'Donnell, 1993), and the internal transcribed spacers ITS and the 5.8S ribosomal gene were amplified using the external primers ITS-1 and ITS-4 (White et al., 1990). PCR reactions were performed in a PROGENE thermocycler (Techne) as follows: a first denaturation step at $95^{\circ} \mathrm{C}$ for $5 \mathrm{~min}$, followed by 40 cycles of $94^{\circ} \mathrm{C}$ for $40 \mathrm{~s}$, $55^{\circ} \mathrm{C}$ for $40 \mathrm{~s}$ and $72^{\circ} \mathrm{C}$ for $30 \mathrm{~s}$, with a final extension of $10 \mathrm{~min}$ at $72^{\circ} \mathrm{C}$. The PCR products were cleaned with the Perfectprep Gel Cleanup (Eppendorf) and then directly sequenced using the BigDye terminator version 3.1 cycle sequencing kit (Applied Biosystems), following the manufacturer's instructions, in an Applied Biosystems automatic DNA sequencer, model 310. Primers NL-1 and NL-4 were used in the sequencing reactions to read both DNA strands of D1 and D2 domains of the 26S rRNA gene, and primers ITS- 1 and ITS-4 were used in the sequencing reactions to read both DNA strands of the ITS1-5.8SITS2 rDNA region.

Sequences of the D1/D2 region of the 26S rRNA gene were edited and assembled using MEGA version 3.1 software (Kumar et al., 2004), and then subjected to a GenBank BLASTN search to retrieve sequences of closely related taxa.

The sequences of the D1/D2 region of the 26S rRNA gene were included in a multiple alignment generated using MEGA version 3.1. The Kimura two-parameter model was used for distance correction, and the neighbour-joining method (Saitou \& Nei, 1987) was used for phylogenetic inference. Support for tree branches was evaluated by bootstrap analysis from 1000 heuristic searches (MEGA version 3.1). Sequence AF189901 representing the D1/D2 ribosomal region of Kondoa aeria CBS $8352^{\mathrm{T}}$ was used as the tree outgroup.

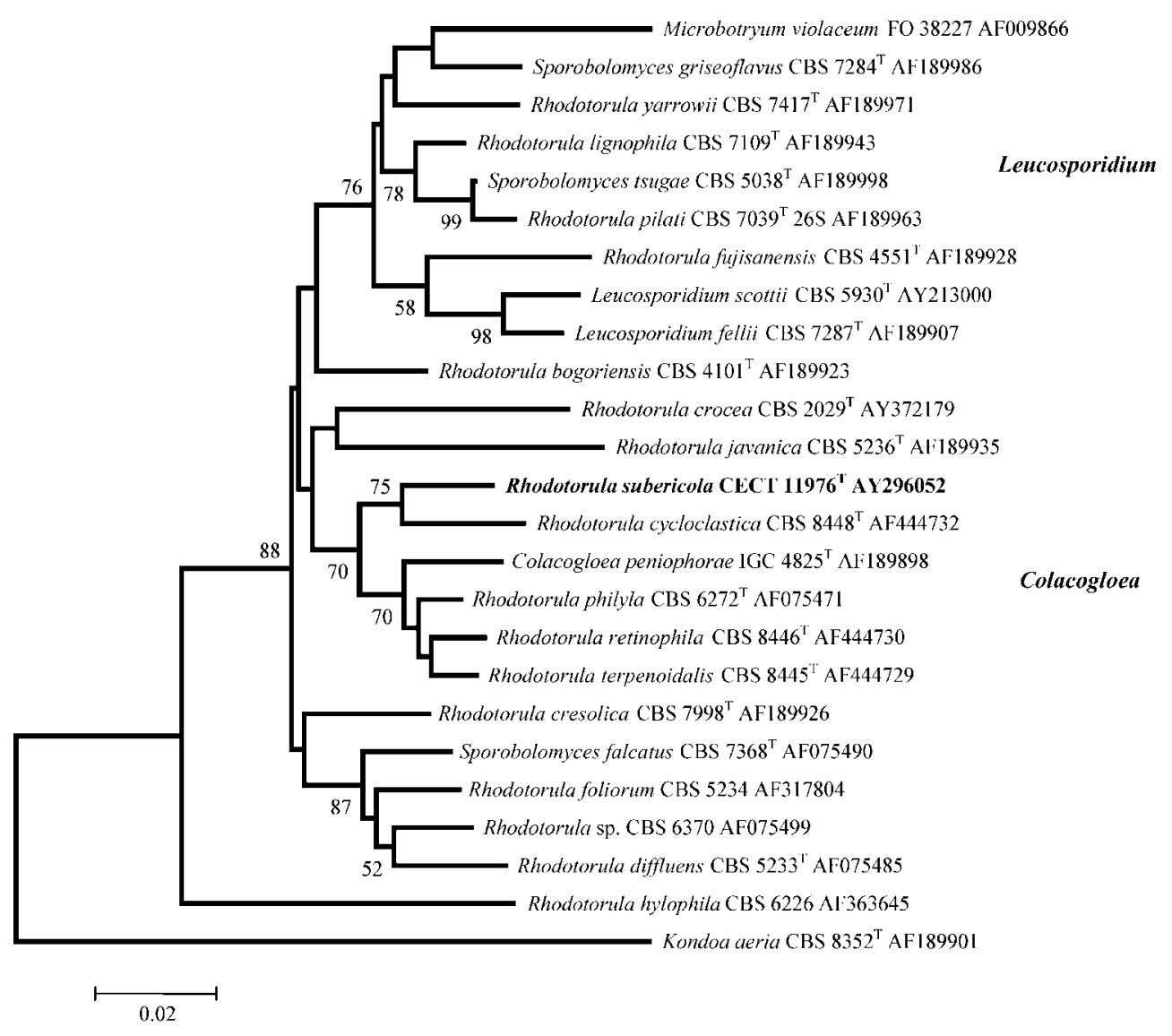

Fig. 1. Phylogenetic tree reconstructed using the neighbour-joining method, depicting relationships between species in the Microbotryum lineage. The tree was constructed based on nucleotide divergences in the D1/D2 region of the 26S rRNA gene using the program MEGA 3.1. Bootstrap values for frequencies less than $50 \%$ are not given. GenBank accession numbers of sequences are given after the species names. Outgroup: Kondoa aeria. 


\section{Phylogenetic position of $\mathrm{Y}-31^{\mathrm{T}}$ and $\mathrm{Y}-20 \mathrm{~B}$ and phenotypic comparison with closely related species}

Sequence variability within $\mathrm{Y}-31^{\mathrm{T}}$ and $\mathrm{Y}-20 \mathrm{~B}$ was absent in the D1/D2 region of the $26 \mathrm{~S}$ rRNA gene and the ITS-5.8S rDNA region.

Phylogenetic analysis based on the D1/D2 region sequences indicated that the closest relative (75\% bootstrap) to $R$. subericola was $R$. cycloclastica (Fig. 1). Alignment of the $\mathrm{D} 1 / \mathrm{D} 2$ region sequences of the novel isolates and related taxa revealed $25 \mathrm{bp}$ substitutions in 644 positions (96\% sequence identity) between the novel isolates and $R$. cycloclastica. These species cluster in a group (70\% bootstrap) with $R$. retinophila, $R$. terpenoidalis, Colacogloea peniophorae and R. philyla in the Microbotryum lineage. The Microbotryum lineage pertains to the subclass Microbotryomycetidae in the class Urediniomycetes of basidiomycetous yeasts (Scorzetti et al., 2002). The class Urediniomycetes is divided into four lineages: Microbotryum, Sporidiobolus, Erythrobasidium and Agaricostilbum. Scorzetti et al. (2002) divided the Microbotryum lineage into two weak clades, namely Colacogloea and Leucosporidium. Phylogenetic reconstructions including most of the members in the Microbotryum lineage (Alvaro Fonseca, 2004) produced a tree similar to the one reconstructed by Scorzetti et al. (2002). In the present study, the Microbotryum lineage appears to be divided into three clusters, Leucosporidium (76\% bootstrap), Colacogloea (70\% bootstrap) and a third cluster ( $87 \%$ bootstrap) composed of the species Sporobolomyces falcatus, Rhodotorula foliorum, Rhodotorula sp. CBS 6370 and Rhodotorula diffluens. The lineage Microbotryum includes, in addition to members of the genera Rhodotorula, species from the genera Sporobolomyces, Leucosporidium and Colacogloea. Other members of the polyphyletic anamorphic genus Rhodotorula can also be found in the lineages Erythrobasidium and Sporidiobolus Scorzetti et al. (2002).

Physiological differences between the members of the cluster where $\mathrm{Y}-31^{\mathrm{T}}$ and $\mathrm{Y}-20 \mathrm{~B}$ were included ranged from four to eight properties (Table 1 ). $\mathrm{Y}-31^{\mathrm{T}}$ and $\mathrm{Y}-20 \mathrm{~B}$ were the only members of the group able to use galactose as sole carbon source and nitrate as sole nitrogen source. $\mathrm{Y}-31^{\mathrm{T}}$ and $\mathrm{Y}-20 \mathrm{~B}$ were investigated for basidiospore formation on cornmeal agar, $5 \%$ malt extract agar and sucrose-yeast extract agar, but after 6 weeks of growth and observation no basidiospores were found. A loopful of cells of each isolate was mixed on a plate of cornmeal agar to obtain a dikaryotic hyphal phase, but after several days of observation no hyphal growth was detected, therefore we concluded that mating did not occur between the two isolates.

\section{Latin diagnosis of Rhodotorula subericola Belloch, Villa-Carvajal, Álvarez-Rodríguez et Coque sp. nov.}

In medio liquido dextrosum et peptonum et extractum levidinis continenti post 3 dies ad $25^{\circ} \mathrm{C}$ cellulae sunt singulae aut
Table 1. Physiological properties differentiating $R$. subericola sp. nov. from phylogenetically related species

$1, R$. subericola sp. nov.; 2, R. cycloclastica; 3, R. retinophila; 4, R. terpenoidalis; $5, R$. philyla. + , Positive; -, negative; V, variable; $\mathrm{s}$, slow; W, weak. Physiological properties common to all species were assimilation of D-glucose, trehalose, succinate, citrate, glucitol, mannitol, ribitol, ethanol and urease, and all grew on vitamin-free medium. All species were negative for assimilation of sorbose, cellobiose, lactose, melibiose, raffinose, L-arabinose, Dribose, D-glucosamine, inulin, soluble starch, L-rhamnose, glycerol, erythritol, galactitol, inositol, methanol and salicin. No species produced deeply pigmented colonies (orange, pink or red), produced starch-like compounds or grew on $\mathrm{NaCl}$ plus $5 \%$ glucose.

\begin{tabular}{|lccccc|}
\hline Characteristic & $\mathbf{1}$ & $\mathbf{2}^{*}$ & $\mathbf{3}^{*}$ & $\mathbf{4}^{*}$ & $\mathbf{5} \dagger$ \\
\hline Assimilation of: & & & & & \\
D-Galactose & + & - & - & - & - \\
Maltose & - & - & - & + & - \\
Sucrose & + & - & - & + & - \\
Melezitose & - & - & - & + & - \\
D-Arabinose & $\mathrm{S}$ & - & + & + & - \\
D-Xylose & + & - & + & + & $\mathrm{V}$ \\
DL-Lactate & - & - & $\mathrm{W}$ & $\mathrm{W}$ & - \\
D-Gluconate & + & - & + & + & + \\
Methyl $\alpha$-D-glucoside & - & - & - & + & - \\
D-Glucuronate & + & - & + & - & + \\
Nitrate & + & - & - & - & - \\
Growth at $37^{\circ} \mathrm{C}$ & - & - & + & $\mathrm{W}$ & - \\
\hline
\end{tabular}

${ }^{\star}$ Data from Thanh et al. (2004).

$\dagger$ Data from Fell \& Statzell-Tallman (1998).

binae, ovoidae aut cylindricae, $1.5-3 \times 3.5-7 \mu \mathrm{m}$. Post unum mensem sedimentum adest. In agaro malti cultura aquosa mucosescens vel glutinosescens, partim cremea, impellucida, glabra, nitida. Pseudomycelium non formantur. Fermentatio

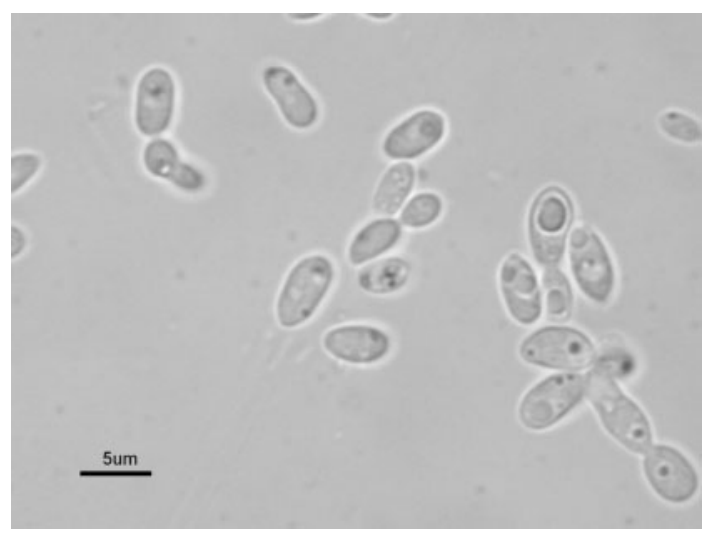

Fig. 2. Vegetative cells of $\mathrm{Y}-31^{\top}\left(=\mathrm{CECT} 11976^{\top}\right)$ grown on malt extract for 3 days at $25^{\circ} \mathrm{C}$. The image was taken with a digital Nikon DXM1200F camera under light field mode. Bar, $5 \mu \mathrm{m}$. 
nulla. D-Glucosum, sucrosum, $\alpha$-trehalosum, D-glucitolum, D-mannitolum, ribitolum, ethanolum, D-gluconatum, Dglucosaminum, N-acetyl-D-glucosaminum, D-glucuronatum, citratum, succinatum, xylitolum assimilantur, at non D-galactosum, L-sorbosum, cellobiosum, lactosum, maltosum, melibiosum, melezitosum, raffinosum, inulinum, amylum solubile, D-arabinosum, L-arabinosum, D-ribosum, D-xylosum, L-rhamnosum, glycerolum, erythritolum, L-arabinitolum, galactitolum, meso-inositolum, methanolum, DLlactatum, methyl $\alpha$-D-glucosidum, salicinum, hexadecanum nec saccharatum. Glucosminum, L-lysinum, natrium nitricum et natrium nitrosum assimilantur neque ethylaminum et imidazolum. Sine vitaminis externis supplementis crescens. Maxima temperatura crescentiae: $30^{\circ} \mathrm{C}$. Gelatinum non liquescit et arbutinum non finditur. Acidum non formantur. Non crescit in $50 \%$ glucoso. Materia amyloidea non formantur. Ureum hydrolysatur.

Typus: $\mathrm{Y}-31^{\mathrm{T}}$ (=CECT $\left.11976^{\mathrm{T}}=\mathrm{CBS} 10442^{\mathrm{T}}\right)$, ex suber isolata. Holotypus lyophilus conservatur in collectione culturarum Colección Española de Cultivos Tipo, Hispania.

\section{Description of Rhodotorula subericola Belloch, Villa-Carvajal, Álvarez-Rodríguez \& Coque}

\section{sp. nov.}

Rhodotorula subericola [su.be.ri'co.la. L. n. suber -eris the cork-oak, cork-tree, cork; L. suff. -cola (from L. n. incola) inhabitant, dweller; N.L. n. subericola inhabitant of cork tree, cork].

In GPY medium after 3 days at $25^{\circ} \mathrm{C}$, cells are ovoid to cylindrical $(1.5-3 \times 3.5-7 \mu \mathrm{m})$ and occur singly or in parent-bud pairs (Fig. 2). After 1 month at $25^{\circ} \mathrm{C}$, sediment is present. Streak culture on malt agar is viscous to mucoid, partly hyaline, partly creamish-opaque, smooth and glistening. No true hyphae or pseudohyphae develop in Dalmau plate cultures. Fermentation is negative. It assimilates D-glucose, sucrose, $\alpha$-trehalose, D-arabinose, D-xylose, D-glucitol, D-mannitol, ribitol, ethanol, citrate (weak), succinate, D-gluconate, D-glucosamine, $\mathrm{N}$-acetyl-D-glucosamine, D-glucuronate and xylitol. Does not assimilate Dgalactose, L-sorbose, cellobiose, lactose, maltose, melibiose, melezitose, raffinose, inulin, soluble starch, L-arabinose, D-ribose, L-rhamnose, glycerol, erythritol, L-arabinitol, galactitol, inositol, methanol, DL-lactate, methyl $\alpha$-D-glucoside, salicin, hexadecane or saccharate. Assimilation of nitrogen compounds: positive for nitrate, nitrite, L-lysine and glucosamine, negative for ethylamine and imidazole. Growth in vitamin-free medium is positive. Growth at 25 and $30{ }^{\circ} \mathrm{C}$ is positive. Growth at $37^{\circ} \mathrm{C}$ is negative. Gelatin liquefaction and arbutin hydrolysis are negative. Acid formation on chalk agar is negative. Growth on $50 \%$ glucose/yeast extract is negative. No starch-like substance is produced. Urease activity is positive.

The type strain, Y-31 ${ }^{\mathrm{T}}\left(=\mathrm{CECT} 11976^{\mathrm{T}}=\mathrm{CBS} 10442^{\mathrm{T}}\right)$, was isolated from a cork sample in Spain.

\section{References}

Álvarez-Rodríguez, M. L., Lopez-Ocaña, L., Lopez-Coronado, J. M., Rodriguez, E., Martinez, M. J., Larriba, G. \& Coque, J.-J. R. (2002). Cork taint of wines: role of the filamentous fungi isolated from cork in the formation of 2,4,6-trichloroanisole by O methylation of 2,4,6trichlorophenol. Appl Environ Microbiol 68, 5860-5869.

Álvarez-Rodríguez, M. L., Belloch, C., Villa, M., Uruburu, F., Larriba, G. \& Coque, J.-J. R. (2003). Degradation of vanillic acid and production of guaiacol by microorganisms isolated from cork samples. FEMS Microbiol Lett 220, 49-55.

Alvaro Fonseca, J. I. (2004). Reinstatement of Rhodotorula colostri (Castelli) Lodder and Rhodotorula crocea Shifrine \& Phaff, former synonyms of Rhodotorula aurantiaca (Saito) Lodder. FEMS Yeast Res 4, 557-561.

Fell, J. W. \& Statzell-Tallman, A. (1998). Rhodotorula F.C. Harrison. In The Yeasts: a Taxonomic Study, 4th edn, pp. 800-827. Edited by C. Kurtzman \& J. W. Fell. Amsterdam: Elsevier Science Publishers.

Kumar, S., Tamura, K. \& Nei, M. (2004). MEGA3: integrated software for Molecular Evolutionary Genetics Analysis and sequence alignment. Bioinformatics 5, 150-163.

O'Donnell, K. (1993). Fusarium and its near relatives. In The Fungal Holomorph: Mitotic, Meiotic and Pleomorphic Speciation in Fungal Systematics, pp. 225-233. Edited by D. R. Reynolds \& J. W. Taylor. Wallingford, UK: CAB International.

Saitou, N. \& Nei, M. (1987). The neighbour-joining method: a new method for reconstructing phylogenetic trees. Mol Biol Evol 4, 406-425.

Scorzetti, G., Fell, J. W., Fonseca, A. \& Statzell-Tallman, A. (2002). Systematics of basidiomycetous yeasts: a comparison of large subunit D1/D2 and internal transcribed spacer rDNA regions. FEMS Yeast Res 2, 495-517.

Thanh, V. N., Smit, M. S., Moleleki, N. \& Fell, J. W. (2004). Rhodotorula cycloclastica sp. nov., Rhodotorula retinophila sp. nov., and Rhodotorula terpenoidalis sp. nov., three limonene-utilizing yeasts isolated from soil. FEMS Yeast Res 4, 857-863.

Villa-Carvajal, M., Coque, J.-J. R., Alvarez-Rodriguez, M. L., Uruburu, F. \& Belloch, C. (2004). Polyphasic identification of yeasts isolated from bark of cork oak during the manufacturing process of cork stoppers. FEMS Yeast Res 4, 745-750.

White, T. J., Bruns, T., Lee, S. \& Taylor, J. W. (1990). Amplification and direct sequencing of fungal ribosomal RNA genes for phylogenetics. In PCR Protocols: a Guide to Methods and Applications, pp. 315-322. Edited by M. A. Innis, D. H. Gelfand, J. J. Sninsky \& T. J. White. New York: Academic Press.

Yarrow, D. (1998). Methods for the isolation, maintenance and identification of yeasts. In The Yeasts: a Taxonomic Study, 4th edn, pp. 77-100. Edited by C. Kurtzman \& J. W. Fell. Amsterdam: Elsevier Science Publishers. 